DOI: $10.15593 / 978-5-398-02346-6 / 2020.11$

\title{
МУЗЕЕФИКАЦИЯ ТЕМЫ
}

«ТРАМОВСКОЕ ДВИЖЕНИЕ В КУНГУРЕ В 20-30-Е ГГ.

ХХ В.» В КУНГУРСКОМ МУЗЕЕ-ЗАПОВЕДНИКЕ

\author{
Л.Ю. Елтынева, \\ заведуюший отделом истории, \\ Кунгурский историко-архитектурныи \\ и художественный музей-заповедник, Кунгур \\ Larisa-1408@yandex.ru
}

Аннотация. Рассматриваются история трамовского движения в Кунгуре в 20-е гг. XX в. и музеефикация данной темы в фондах Кунгурского музея-заповедника.

Ключевые слова: театр; «Живая газета»; ГУЛАГ; музей.

\section{MUSEIFICATION OF THE THEME «TRAMOV MOVEMENT IN KUNGUR IN 20-30-IES OF XX CENTURY.» IN KUNGUR MUSEUM-RESERVE}

\author{
L.Yu. Eltysheva, \\ Head ofDepartment of history, Kungur historical, \\ architectural and art Museum-reserve, Kungur \\ Larisa-1408@yandex.ru
}

Summary. The article is about the history of Tramov movements in Kungur in the 20s of the XX century and museification of this topic in the collections of the Kungur Museum-reserve. Museum.

Keywords: theatre; The young Communist League; Live newspaper;

Воспоминания и личные фонды кунгуряков оставили яркие страницы культурной жизни провинциального города. Основы трамовского движения в Кунгуре были заложены еще в начале XX в. через деятельность различных театральных коллективов. В 1902 г. в Кунгуре работало «Общество любителей сцены». Оно было соз- 
дано по инициативе «Кунгурского общества пособия учащимся и попечения о народном образовании» и супругов Агеевых. Сначала «Общество любителей сцены» ставило перед собой цель организации музыкально-литературных вечеров и сбора средств на обучение бедных учеников. Затем оно стало центром любительской театральной жизни города. По инициативе супругов Агеевых и при их участии проходили благотворительные вечера, спектакли. Ставили любительские спектакли. Супруги Агеевы играли большую роль в культурной жизни города. В одном из зданий завода Агеевыми был оборудован театр, больше известный в Кунгуре как «Агеевский клуб». Была оборудована сцена, закуплено необходимое оборудование. Сами Агеевы принимали активное участие в постановках спектаклей. Их дочь Валерия вспоминала: «Дом наш соединялся крытой летней галереей с небольшим театром, тоже нам принадлежавшим. Там играла приезжая труппа вместе с местными любителями. Почти все главные роли исполнял сам папа, будучи очень талантливым актером. Кроме того папа чудно декламировал и пел. Каждая пьеса обставлялась стараниями папы домашними способами, но очень искусно и естественно, судя по карточкам. Например, снимки из "Горя от ума". Право, можно было забыть, что это сцена провинциального театра. Устраивались в доме и детские спектакли. Костюмы шили сами, стараясь соответствовать той эпохе. Не обходилось и без курьезов во время спектаклей. Однажды ставили спектакль в летнем саду. На него пришел постоянный зритель - местный священник. Но так как ему нельзя было находиться в зрительном зале, то батюшка занимал место за кулисами и оттуда ухитрялся наблюдать за тем, что происходило на сцене. Однажды во время спектакля он, видимо, не сохранил равновесие и больше чем надо навалился на кулису. Она упала, и перед взором публики появилась фигура священника во всем ее величии. Актеры, вершившие свое действие на сцене, были смущены, но больше всех был смущен сам виновник» [2, с. 67]. А.Г. Агеев переложил в драму роман Э. Войнич «Овод». Впервые эта драма на русской сцене была сыграна именно в Агеевском театре. Летом 1902 г. было поставлено насколько несложных, одноактных спектаклей в городском саду. Скоро такие постановки стали заметными в городе, о них заговорили. Это в свою очередь окрыляло любителей сцены. Актеры стали ответственно относиться к своему делу, совершенствовать мастерство. 20 августа 
1903 г. устроен А.Г. Агеевым спектакль по И.С. Тургеневу «Отцы и дети» в пользу Общества пособия учащимся с выручкой 80 рублей. Летом 1903 г. был поставлен спектакль по роману И.С. Тургенева «Отцы и дети», артисты приступили к подготовке спектакля по пьесе А.С. Грибоедова «Горе от ума». В 1905 г. труппой представлен спектакль «Свадьба Кречинского». В 1912 г. устроенный спектакль «Иван Миронич» принес 116 рублей благотворительных взносов [12, с. 50]. В годы Первой мировой войны в городе располагался 153-й запасной пехотный полк. По воспоминаниям бывшего офицера Н.П. Важенцева, «при гарнизонном комитете был организован “культурно-просветительный комитет”. Сюда для работы были приглашены лучшие силы местной интеллигенции и учительства. Имелся полковой театр, помещавшийся в бывшем здании пчеловодного музея. Здесь продолжительное время работа украинская труппа, организованная из полковых солдат» [1, с. 2].

После событий февраля и октября 1917 г. театральная деятельность в Кунгуре приобретает новые революционные черты. В 1918 г. по воспоминаниям В.А. Агеевой театр ее родителей после их расстрела карательным отрядом был реквизирован со второго дня пасхи 1918 г., и там стали ставить спектакли местные любители сцены под руководством главного артиста любителя Г.М. Пивоварова [2, с. 69]. В октябре 1918 г. в клубе партии коммунистов в доме Елтышева у Сылвенского моста под режиссерством Г.М. Пивоварова группа артистов и любителей ставила драмы «Каторжанин», «Соколы и воры» [3, с. 26]. В первой половине 1919 г. в Кунгуре работали общественные организации: Комитет помощи Народной армии, Кунгурский дамский кружок, Общество художников, Кунгурское учительское общество, Кунгурское отделение Российского общества Красного Креста [6, с. 4]. Эти общественные организации ставили различные спектакли, концерты. 23 марта 1919 г. в здании технического училища Общество художников устроило большой вечер-бал. 20 \% общего сбора поступило в пользу Народной армии. В программе сообщалось: «Спектакль “Вова революционер”, аукцион (разыгрывался сажень дров с доставкой на дом), дивертисмент. Работает школа рисования для детей» [7, с. 4]. 5 апреля 1919 г. в помещении электро-театра «Люкс» в пользу Кунгурского врачебнораспределительного пункта был дан вокально-хореографический вечер артисток Московского балета Ольги Вронской, Сандры Станиславской и артисток оперы Адиной и Мусиной [8, с. 4]. 
В 20-е гг. в стране создается и ширится трамовское движение. Первый Театр рабочей молодежи был создан в Ленинграде в 1925 г. Затем они стали появляться и по всей стране. Основной принцип таких театров - агитация и воздействие на трудящиеся массы. В их инсценировках всегда непримиримо сталкивались рабочие и самодержавие, Красная и белая армии и т.д. «Живая газета» пропагандировала идеи пролетарской солидарности, высмеивала западных политиков. Ее участники смело применяли агитационные приемы воздействия на зрителя. Это спортивные упражнения, хоровое пение, световые и звуковые эффекты. В инсценировках демонстрировались митинги, военные парады. Клубный театр был театром социальной маски. В действиях непременно присутствовали политические «маски»: капиталист, генерал, соглашатель, поп. Актеры, не перевоплощаясь в образ, двумя, тремя резкими штрихами, всегда одинаковыми, намечали ту или иную типажную фигуру. Буржуй - сытый, в цилиндре, генерал - «кровожадный», с кривой шашкой, соглашатель - трусливый, в шутовском костюме. В «Живой театрализованной газете» (ЖТГ) наряду с политическими масками появлялись бытовые: хулиган, прогульщик, растратчик, бюллетенщик. Днем актеры трамов трудились на заводах, учились, а вечером спешили на репетиции или выезжали на спектакли [11, с. 21].

В 1928 г. в Кунгуре создается студия живой театрализованной газеты «Пятилетка», которой руководил И.А. Крылов. Ставились пьесы разных жанров, затем перешли на метод работы «синеблузников» (рис. 1-3). Ставились так называемые политические оратории на стихи Маяковского, Светлова, Безымянного. «Живгазетчики» очень оперативно откликались на все текущие события в стране, знаменательные даты. В своих выступлениях «живгазетчики» использовали острые критические материалы из местной жизни. Побаивались выступления ЖТГ бюрократы, жулики, пьяницы.

В редактировании таких материалов участвовал работник Окрпрофсовета товарищ Юрганов. ЖТГ г. Кунгура пользовалась большим успехом у соседей, выезжали с соседние районы. Днем работали в поле, вечерами в школах в избах-читальнях или просто на улице показывали программу. В 30-е гг. проходили тиражи «Крестьянского займа». Вот в таких мероприятиях тоже принимали участие артисты ЖТГ. 


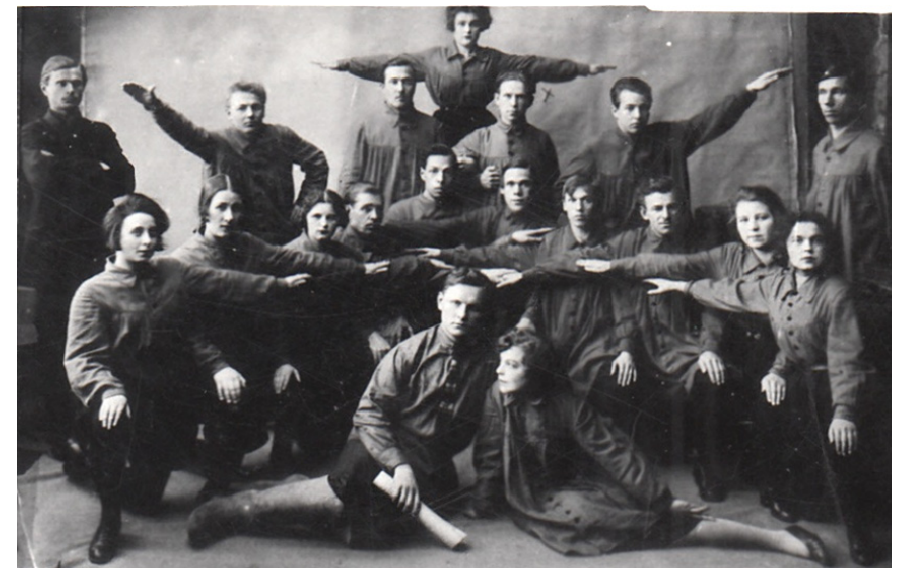

Рис. 1. Группа ораторий живой театрализованной газеты «Пятилетка», г. Кунгур, 1928 г.

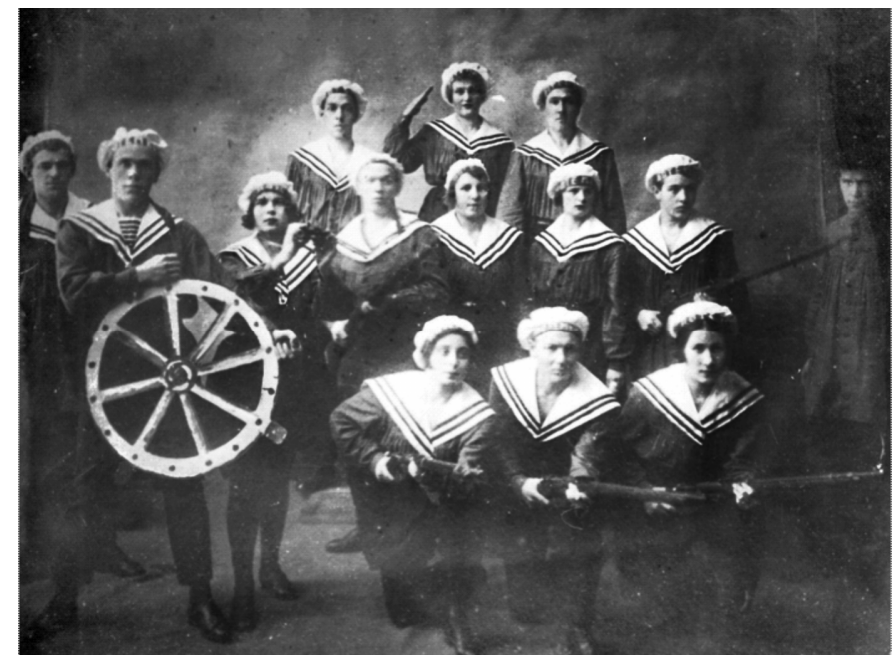

Рис. 2. Участники живой театрализованной газеты «Пятилетка». Руководитель И.А. Крылов, г. Кунгур, 1928 г. 


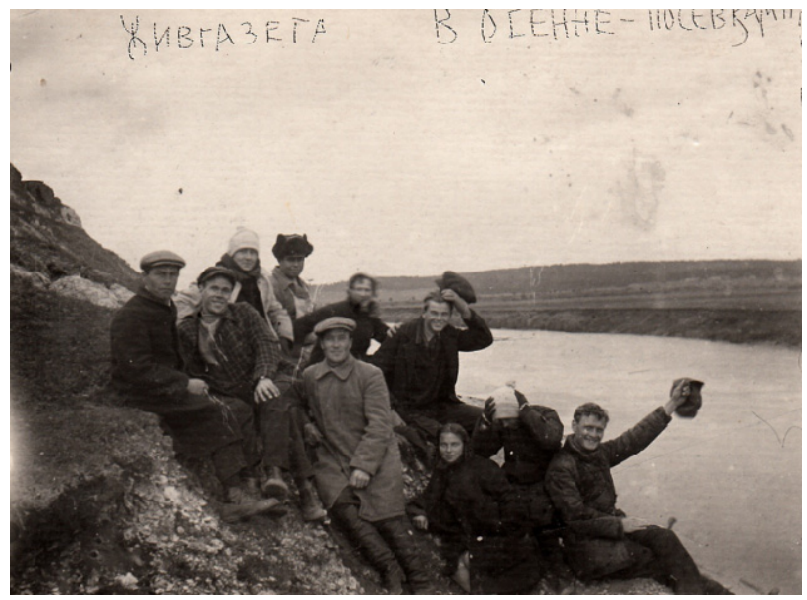

Рис. 3. Участники живой театрализованной газеты «Пятилетка» во время осенней уборочной компании в с. Кочебахтино Кунгурского района, 1930 г.

Частыми были и поездки в Пермь. Основными актерами ЖТГ были М.Г. Бушуев, впоследствии профессиональный актер, И.Ф. Серебряков, Л. Брацун и другие (рис. 4). Среди активных «живгазетчиков» были музыканты Г. Красных, скрипач В. Лебедев, пианистка Врублевская [13, с. 2].

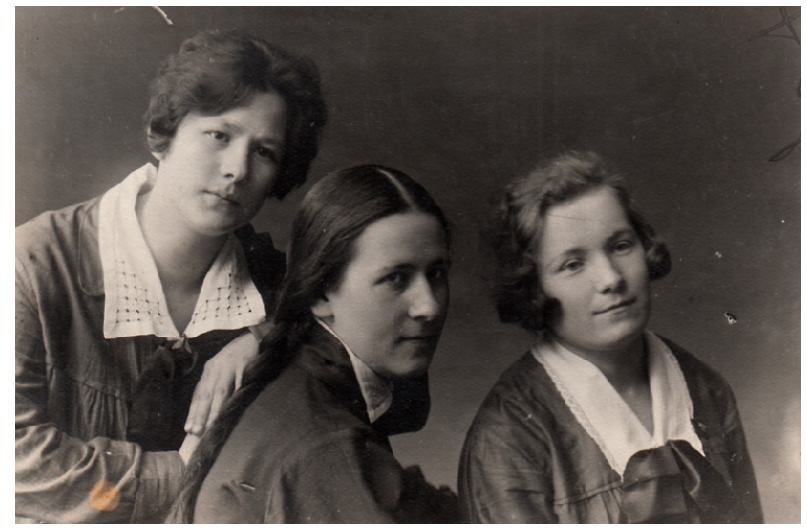

Рис. 4. Живгазетчицы Н. Беляева, Л. Юрганова, О. Серебрякова, 1931 г. 
Участники группы «Синеблузников» одевались в одинаковые синие блузы, на груди имелся значок «ЖТГ». Он представлен в экспозиции Кунгурского музея-заповедника, как и фотографии ЖТГ «Синяя блуза» (рис. 5).

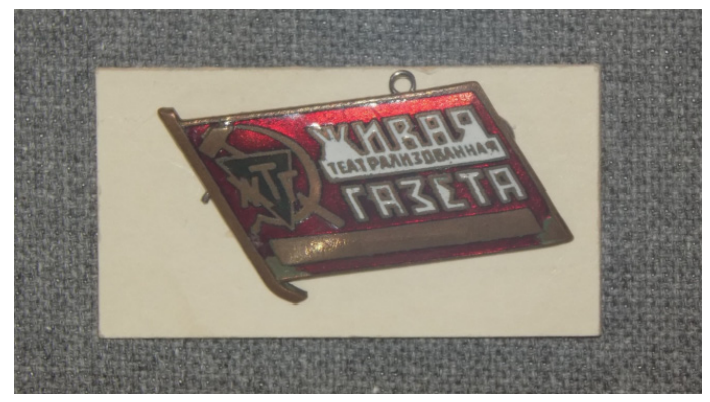

Рис. 5. Знак ЖТГ (Живой театрализованной газеты).

Принадлежал Л.Г. Кичигиной, Кунгурский музей-заповедник

В Кунгуре театрализованные коллективы «Синяя блуза», «Живая газета» действовали в школе 2-й ступени, в педагогическом и механическом техникумах, в клубе железнодорожников, где большим энтузиастом этих процессов был артист драмкружка Н. Мокрушин (рис. 6).

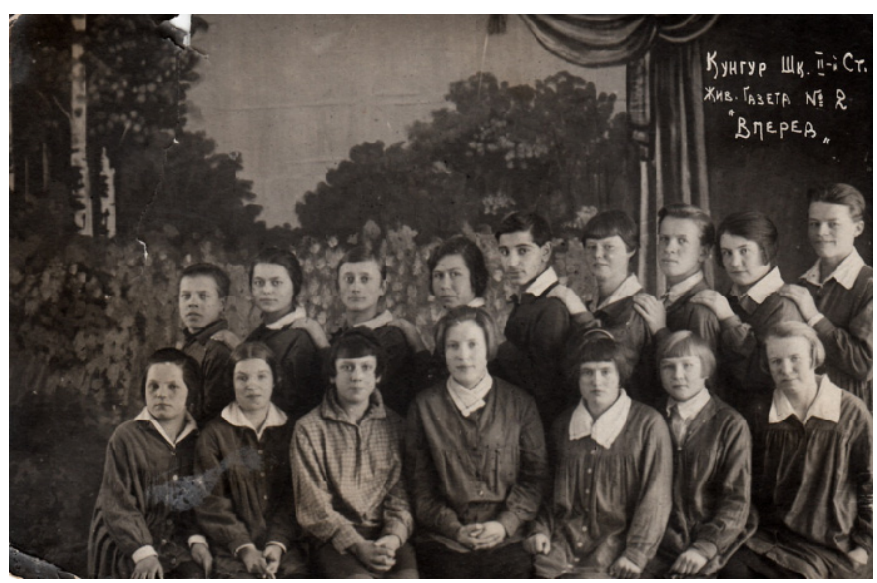

Рис. 6. Живая газета «Вперед» № 2 школы II ступени г. Кунгура, 1931 г. 


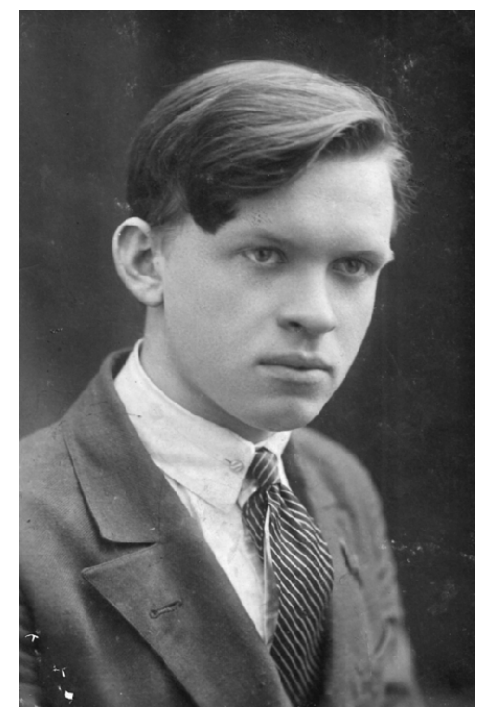

Рис. 7. И.Ф. Серебряков, руководитель живой театрализованной газеты «Вперед» при клубе СТС (Совторгслужащих), г. Кунгур, 30-е гг. XX в.
Иувиналий Филимонович Серебряков (1913-2002) родился в Кунгуре. Окончил семь классов школеы II ступени. В период учебы в школе руководил живой театрализованной газетой «Вперед», органам горкома ВКП(б) и Горпрофсовета при клубе «С.Т.С.» В 1935 г. окончил в Перми курсы техников-конструкторов. Там же в Перми был руководителем художественной самодеятельности клуба «Профинтерн». Занимался организацией студии областного Театра рабочей молодежи, был лаборантом, режиссером и актером. Впоследствии был художественным руководителем клуба «Обувщик» [4, с. 1-6]. В фондах музея хранится личное дело И.Ф. Серебрякова, насчитывающее более 100 единиц хранения (рис. 7).

Журналист, фотокорреспондент А.П. Шадрин вспоминал: «Мы - живгазетчики, мы - синеблузники! Так обычно начиналось театральное представление на сценах рабочих клубов нашего маленького г. Кунгура в 20-е годы. Вспоминаю, как “живгазетчики” клуба кожевников просмеивали белоэмигрантов. По сцене кружили двое толстяков, у одного из них барабан на брюхе, у другого скрипка. Жалобными голосами пели слезливую частушку: “Ходим мы по улицам Парижа. У меня от барабана грыжа”. А распевал ее знаменитый в Кунгуре самодеятельный артист Михаил Бушуев» [14, с. 3]. Сам А.П. Шадрин в 1933 г., будучи 16-летним подростком и начитавшись книг о террористической организации «Народная воля», организовал в Кунгуре кружок «Вольнодумье» (рис. 8). Восемь друзей-единомышленников приняли устав, спорили и рассуждали, как живется людям в Кунгуре. Члены кружка определили 
своей целью «принесение жизни и здоровья каждого члена кружка, а также средств для улучшения жизни пролетариата». Подростки отправили письмо Сталину, где не только описали тяжелое положение кунгуряков, но и выдвинули свои требования: «Уважаемый товарищ Сталин! Вы козырный временщик. Вы не знаете, как страдает русский народ. Например, на Урале, в Кунгурском районе народ весь истощен. Крестьяне оставлены без хлеба и голодают.

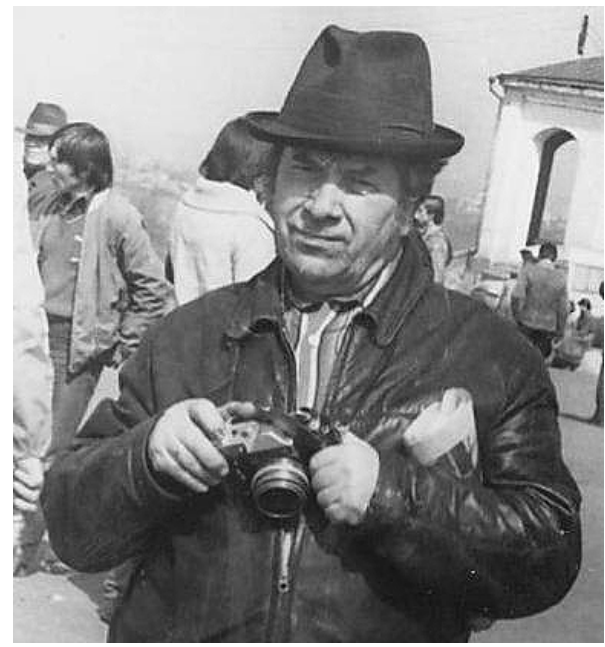

Рис. 8. А.П. Шадрин В 1931-1933 годах они ели суррогат вперемежку с хлебом, а иногда и голый суррогат из листьев крапивы, древесной коры, мякины. Кунгурская организация “Вольнодумье” предъявляет Вам следующие требования: “Свобода слова, мысли, печати, вольная торговля, государственная торговля хлебом, свободные выборы представителей народа от каждого города, свобода всех сословий”. Если наши требования не будут выполнены, то знайте.....» [9, с. 382].

В 1933 г. А.П. Шадрин сидел во внутренней тюрьме Пермского ОГПУ. С 1935 по 1938 г. - в Кунгурской трудовой коммуне. В ней перевоспитывались, например, подростки из с. Уинское Пермской области. На собрании они решили: «...организоваться и мешать работе драмкружка». Выполняя решение резолюции собрания, «украли два занавеса в избе-читальне». В 1938 г. нескольких воспитанников обвинили в «террористических намерениях». Они «ночью собрались, вели разговоры о тайге, о прочитанных книгах». Другие мальчишки тоже вели разговоры о прочитанных книгах, о «возможности построения гиперболоида инженера Гарина, при помощи которого можно было уничтожить работников НКВД» [15, с. 18]. Журналист, фотокорреспондент, участник Великой Отечественной войны, А.П. Шадрин был осужден дважды: 
в 1933-1938 и в 1948-1956 гг. Второй раз журналист был арестован за хвалебный отзыв о бумаге и фотографиях распространяемого тогда в СССР иллюстрированного журнала «Америка», об американском фильме «Сенатор», который все смотрели в кунгурском кинотеатре. Осложнили его положение и откровенные мысли, изложенные в письме к другу из Свердловской области: «...Меня удивляет равнодушие, с которым мы идем по жизни, шагаем смиренно, с покорностью животных, тупо, как прикажут. И в слепоте своей не видим, что впереди ничего: туман один долгий беспросветный...Люди отупели, думают, что так и быть должно, голоса своего подать не смеют...» [9, С. 383]. Реабилитирован был Александр Павлович в 1964 г. В фондах музея-заповедника хранится личное его дело.

Яркие воспоминания о деятельности трамовского движения в Кунгуре оставил Герман Константинович Ли (1903-1978) (рис. 9).

Он окончил Екатеринбургское реальное училище (1919). Учился в студии Пролеткульта в Свердловске. В 1922 г. поступил на учебу в Кунгурский механический техникум. Из воспоминаний Германа Константиновича:

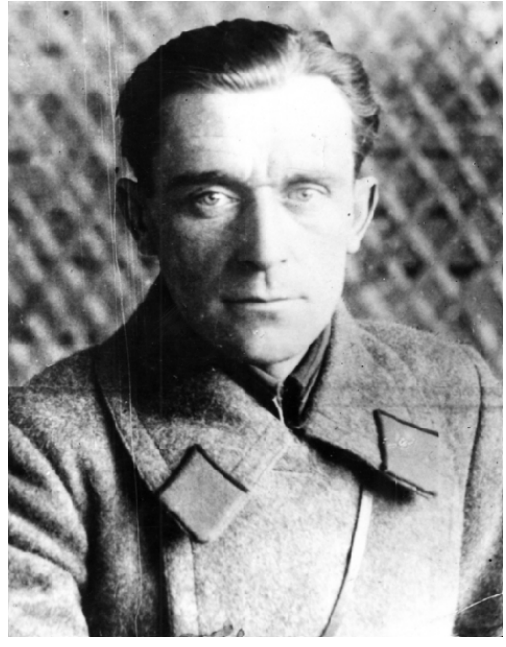

Рис. 9. Г.К. Ли, руководитель группы «Синяя блуза» и редактор стенной газеты «Кузница» в Кунгурском механическом техникуме в 20-е гг. XX в. «Пару слов о нашем внешнем виде. Выглядели мы тогда живописно. Головной убор - кожаная кепка или фуражка. Ну а если буденовка - совсем хорошо. На рубахе воротник обязательно завернут вовнутрь, чтобы грудь была обнаженной. Кое-кто носил военные кителя и мундирчики гимназий и реальных училищ, но пуговицы обязательно обшиты красной материей. На ногах широченные галифе, сшитые из шинельного сукна или из коричневой “чертовой кожи”. Затем обмотки и деревянные сандалии, которые мы мастерили сами. Кожаная обувь была рос- 
кошью и нам не по карману. У девчат красные косынки или кепки, какие-нибудь курточки поверх кофточек, темные юбочки и тоже деревянные сандалии. Никаких галстуков, украшений. Все это считалось буржуазным эстетизмом, мещанством, интеллигентщиной». Во время учебы в механическом техникуме был руководителем группы «Синяя блуза», редактором стенной газеты «Кузница»: «Кроме членства в разных обществах пришлось нести “небольшую” нагрузку: руководил “Синей блузой”. Лозунги того времени: “Без бога шире дорога!”, “Наша этика - долой косметику!”, “Старому театру на горло ставь - мы классового искусства депо и штаб!”» [10, с. 2]. Впоследствии работал в Кунгурском лесотехникуме, был редактором стенной газеты «За кадры». В фондах Кунгурского историкоархитектурного и художественного музея-заповедника хранится неопубликованная рукопись Г.К. Ли «Комсомол 20-х годов» (1968). Его личное дело насчитывает более 100 единиц хранения основного и научно-вспомогательного фонда.

В 1922 г. в Кунгуре при рабочем клубе «Правда» была организована драматическая студия, которой руководил все тот же Г.М. Пивоваров (1888-?) (рис. 10).

Геннадий Михайлович Пивоваров родился в Пермской губернии, Пермском уезде. Служил в 153-м запасном пехотном полку в Кунгуре. В 1919 г. эвакуировался с белой армией как мобилизованный. После служил в Красной армии. В 1927 г. Г.М. Пивоваров как бывший офицер был лишен избирательных прав [5, с. 2]. Геннадий Михайлович не только учил и передавал опыт и знания молодым студийцам, но и заботился о приобретении одежды, дров и других материалов. Драмати-

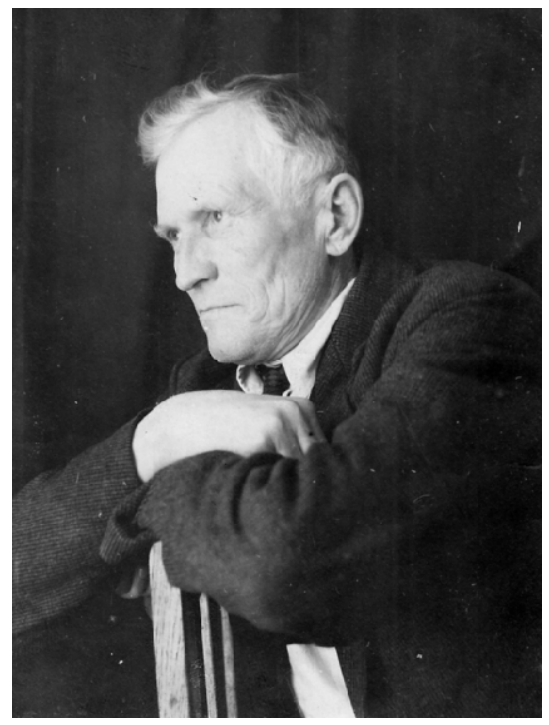

Рис. 10. Г.М. Пивоваров, руководитель драматической студии при рабочем клубе «Правда» в 20-е гг. ХX в. 
ческая студия ставила различные пьесы, в том числе и исторические «Василиса Мелентьева», «Альбина Мечурская», «Борис Годунов», спектакли, концерты. В дальнейшем он руководил театральной студией при клубе «Обувщик». Выступали на сцене электротеатра «Олимп», в летнем театре Мининского парка. Ставились различные спектакли в реалистичном жанре социалистического реализма, концерты. На фотографиях со сценами из спектаклей мы видим инсценировки деревенской жизни, декорации, костюмы и грим - бытоописательные, отражающие жизнь советских людей в 20-30 гг. XX в. На другой фотографии: сцена из постановки пьесы Мольера «Тартюф», режиссер и постановщик М.Г. Бушуев. Изображена последняя сцена спектакля.

Судя по снимку, режиссер сделал постановку бытоописательной, костюмы и грим воспроизводили времена Мольера. М.Г. Бушуев, кунгуряк, всю свою жизнь посвятил театральному искусству. Начинал как актер любитель, впоследствии стал профессиональным актером, работал в одном из театров Казахстана. В фондах музея-заповедника хранится его личное дело. Г.М. Пивоваров избежал репрессий в 30-е гг. ХХ в. Он возглавлял театральную студию клуба «Обувщик» до 50-х гг. ХХ в. В фондах музея есть его личные фотодокументальные источники: это альбом с фотографиями сцен из спектаклей, памятные адреса с 40-летием творческой деятельности, грамоты, юбилейные статьи г. Искра и т.д.

Руководство партии большевиков считало, что искусство должно быть понятно массам настолько, чтобы его можно было с пользой применить для строительства нового мира. Этот подход воплотился в социалистическом реализме, который в 30-е гг. XX в. утвердился в искусстве. В официальной театральной печати началась критика левых или авангардных театров. В том числе стали критиковаться и театры рабочей молодежи, которые причислялись к левым театрам: «Трамы, как и целый ряд левых театров, пройдя через нигилистическое отрицание старой театральной культуры, упрощенно поняв задачу искусства, как голую политическую агитацию, не усвоили ленинского учения о закономерности театрального наследства. Этим и объясняется кризис многих трамовских театров». Авангардное искусство стало сходить на «нет», в стране утвердилось единственное направление в искусстве - социалисти- 
ческий реализм. Некоторые театры рабочей молодежи перешли в статус профессиональных или любительских театров. После 1938 г. в Кунгуре продолжала свою работу драматическая студия при клубе кожевников. Ее режиссерами были Г.М. Пивоваров, И.Ф. Серебряков [13, с. 3]. В фондах Кунгурского музея-заповедника более 260 единиц хранения основного и научно-вспомогательного фонда материалов, рассказывающих о деятельности трамовского движения в Кунгуре в 20-30-е гг., в том числе личные фонды руководителей и участников этого движения.

\section{Список литературы и источников}

1. Важенцев. Н.П. В Кунгурском полку // Искра. 1957. 6 сентября.

2. КГА. Ф.Р-134. ОП. 1. Д. 3.

3. КГА. Ф. 579. ОП. 1. Д. 27.

4. КГА. Ф. 315. Оп. 2. Д. 2576.

5. КГА. Ф-78. Оп. 3. Д. 2. Л.

6. Кунгурский вестник. 1919. 13 марта.

7. Кунгурский вестник. 1919. 24 марта.

8. Кунгурский вестник. 1919. 5 апреля.

9. Лапшина С.Т. «Вольнодумье» кунгуряка А.П. Шадрина // Грибушинские чтения-2019. Кунгурский диалог. Пермь, 2019. C. 382,384 .

10. Ли Г.К. Воспоминания. ККМ. НА. № 207.

11. Миронова В.М. Трам. Агитационный молодежный театр 1920-1930-х гг. Л., 1977.

12. Отчет о деятельности и средствах Общества для пособия учащимся и попечения о народном образовании в г. Кунгуре и Кунгурском уезде за 1912 год. Кунгур: Типография М.Ф. Летунова, 1913.

13. Серебрякова И.Ф. Воспоминания. ККМ: рукопись.

14. Шадрин А.П. Мы - живгазетчики, мы - синеблузники! // Искра. 1988. 28 апреля.

15. Шевырин С.А. Из истории Кунгурской трудовой колонии для несовершеннолетних // Грибушинские чтения-2009. Музей в пространстве и времени. Кунгур, 2009. С. 17. 